W stużbie tradycji i odnowy liturgicznej. 50 lat Instytutu Liturgicznego w Krakowie (1968-2018), red. P. Nowakowski, J. Mieczkowski, Kraków 2019, s. 13-14.

ISBN 978-83-7438-849-8 (wersja drukowana), ISBN 978-83-7438-850-4 (wersja online)

DOI:http://dx.doi.org/10.15633/9788374388504.03

abp Igor Isiczenko

BISKUP CHARKOWSKO-POETAWSKI

Ukraińska Autokefaliczna Cerkiew PrawosŁawna

UKRAINA

\title{
Perspektywa duchowa dyskusji liturgicznych
}

Czcigodni Ojcowie, Szanowni Państwo!

Dla mnie to prawdziwy zaszczyt - obecność tu i słuchanie państwa referatów. Nie jestem naprawdę liturgistą z zawodu, w wymiarze akademickim zajmuję się literaturą ukraińską średniowiecza i baroku. Jednakże i w posłudze biskupiej, i w studiach nad tekstami paraliturgicznymi ciągle jestem połączony z życiem sakramentalnym i z dyskursywnym składnikiem tego życia. Oprócz tego od 24 lat jestem rektorem niewielkiego Kolegium Patriarchy Mścisława w Charkowie, gdzie oczywiście staramy się o należyte nauczanie liturgiczne.

Spotkanie kultury liturgicznej chrześcijańskiego Zachodu i Wschodu ma w mojej opinii wielki potencjał kreatywny. Są rzeczy lepiej widziane z pewnego dystansu obrządkowego. A zastosowanie metodyk z innej dziedziny nauki może być niezwykle pożyteczne dla tworzenia nowego języka i nowego aparatu koncepcyjnego w środowisku, które przeżywa niebezpieczeństwo stagnacji. Jak to już było w Kijowie w epoce metropolity Piotra Mohyły.

Szukanie odnowy liturgicznej i problem jej połączenia się z bardzo ważną dla Wschodu tradycją - to jest jeden z najbardziej bolesnych problemów życia cerkiewnego na Ukrainie. Co to jest nasza tradycja? Czy identyfikuje się ona z epoką patrystyczną, bizantyńską, cyrylo-metodiańską 
starokijowska, kijowsko-mohylańska, moskiewsko-synodalną? Z tym pytaniem kojarzą się najważniejsze problemy osiągnięcia własnej tożsamości chrześcijańskiej.

Dystans kulturalny i konfesyjny może bardzo pomóc w rozwiązaniu tych problemów w wymiarze akademickim.

Moją obecność tu, na sympozjum, zawdzięczam nowatorskiej analizie ojca Przemysława Nowakowskiego o sporach liturgicznych na Ukrainie XVII wieku. Ona to spowodowała dostosowanie do jej akademickiego stylu nowych studiów nad tekstami barokowymi o treści polemicznej, międzykonfesyjnej. I mnie dodała ona odwagi do napisania ubiegłorocznej monografii o „wojnie barokowych metafor” w traktatach polemicznych Kasjana Sakowicza i koła metropolity Piotra Mohyły (por. I. Ісіченко, Вiüна барокових метафор. "Камінь" Петра Могили проти "підзорної труби” Касіяна Саковича, Харків 2017, s. 346).

Prawosławie na Ukrainie przeżywa w tym czasie bardzo ważną transformację. Dla jego uzdrowienia, dla ochrony Cerkwi od interwencji politycznych niewiarygodnie ważne jest wspieranie świadomości tego, że to właśnie życie sakramentalne, liturgiczne, a nie posługa socjalna, jest centrum życia cerkiewnego.

Dlatego jeszcze raz serdecznie dziękuję za radość obecności tu, z państwem, i ufam, że rozszerzenie przestrzeni zróżnicowanych kontaktów liturgistów Europy Zachodniej i Środkowo-Wschodniej ze środowiskami teologicznymi w Ukrainie przyniesie pozytywne wyniki nie tylko w wymiarze akademickim, ale i w całej perspektywie odnowy duchowej naszego kraju, naszej wspólnoty chrześcijańskiej. 